\title{
SOME OBSERVATIONS OF LONG-TAILED JAEGERS IN EARLY AND LATE NESTING SEASONS
}

by Edgar T. Jones, 6115-141st St., Edmonton, Alberta

During the 1966 and 1967 nesting seasons I was filming and working in the Cambridge Bay to Albert Edward Bay regions of Victoria Island, north of Coronation Gulf in the central Canadian Arctic. Since these two nesting seasons were completely different from each other, the following observations of Long-tailed Jaegers (Stercorarius longicaudus) could be of interest. The 1966 season was early, with favorable weather conditions for breeding birds. The 1967 season was two to three weeks later, because of unseasonably cold weather.

The Long-tailed Jaeger during 1966 was a relatively common breeder in the area. Pairs were dispersed roughly one to three miles apart, particularly in the coastal regions. The shorebird populations, on which the Jaeger depends so much, were at a high density with all species present breeding commonly during the first two weeks of July. I found Long-tailed Jaeger nests, each with two eggs, on July 5, 12 and 15. One Pomarine Jaeger and one Parasitic .Taeger nest, each with two eggs, were located on July 10, the Pomarine eggs were pipped. The location of the Long-tailed Jaeger nests was in typical high, barren rocky tundra 50 to 200 feet back from tundra ponds. Adults attacked constantly while the nest was approached and territories were easily located.

In 1967, presumably due to the weather, the Long-tailed Jaeger behaved quite differently. The same areas as in 1966 were visited from July 10 to July 25 and only on July 21 was a nest found (with one egg only). The significant point to me was that there was little if any territorial behaviour. Even the pair with the single egg seemed only mildly interested in defending their territory and after a few dives flew off unconcerned.

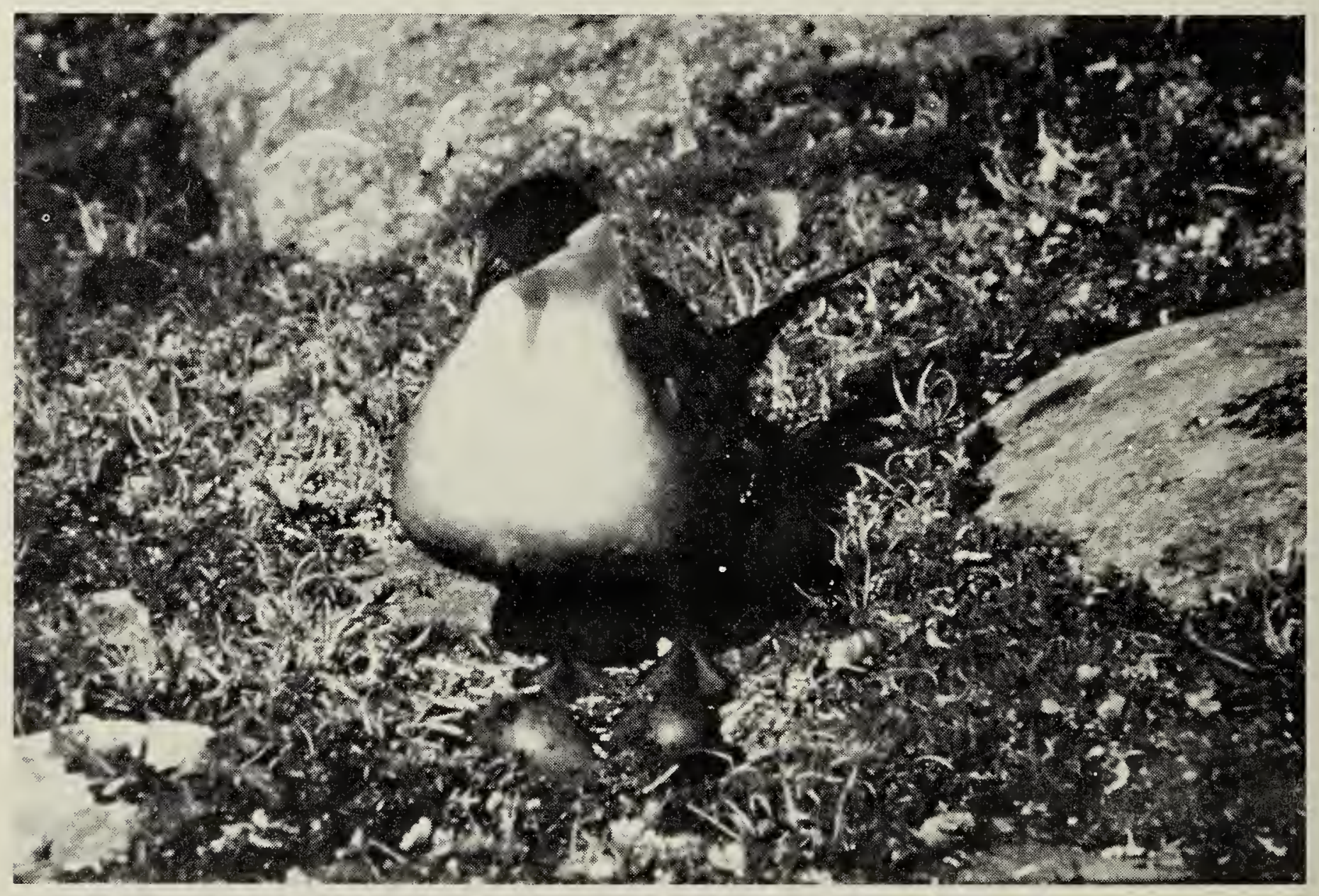

Long-tailed Jaeger at nest

Kodachrome by Edgar T. Jones 
Non-breeding birds seemed to be everywhere and on one occasion a flock of 13 was seen coursing the tundra. It is significant that both lemming and breeding shorebird populations were very much lower in numbers from the 1966 nesting period. It was also noted that both Snowy Owls and Rough-legged Hawks were rare in the 1967 season, yet both nested in 1966. It appears from these observations that in late seasons and when lemming and shorebird populations are low jaegers do not breed.

Arctic vertebrate populations typically fluctuate greatly in numbers. Pitelka (1959) has commented on variations in shorebird populations at Barrow, Alaska and Pitelka, Tomich and Treichel (1955) have discussed the relationship of jaegers and owls to the brown lemming population at
Barrow. Non-breeding of Long-tailed Jaegers in a year following a lemming high was reported in northeast Greenland by Manniche (1910).

\section{Literature Cited}

Manniche, A. L. V. 1910. The terrestrial mammals and birds of northeast Greenland. Danmark Eksped. til Gonlands Nordostkyst 1906-1908. 5 (1) : 1-200.

Pitelka, F. A. 1959. Numbers, breeding schedule, and territoriality in pectoral sandpipers of northern Alaska. The Condor, 61 (4) : 233264.

Pitelka, F. A., P. Q. Tomich and G. W. Treichel. 1955. Ecological relations of jaegers and owls as lemming predators near Barrow, Alaska. Ecol. Monog., 25: 85-117.

\section{ANNUAL MAY DAY BIRD COUNT, SASKATOON}

\section{by J. F. Roy, 120 Maple St., Saskatoon}

This year, 42 observers in eight parties established a record of 146 species, one more than on May 27, 1967, when 29 observers recorded 145 species. The early morning birding was best. By 10 a.m. a strong SSE wind had sprung up, and for the rest of the day the wind ranged from 20 to 30 miles per hour. Temperatures ranged from $47^{\circ}$ at 5 a.m. to a high of $74^{\circ}$. The sky was clear at first, becoming partially clouded in the afternoon with widely scattered showers. Observers drove a total of 1178 partymiles and logged 43 party-miles on foot.

The area covered in the annual May count is a square block consisting of 100 townships $(3,600$ square miles $)$ centering on Saskatoon. Obviously, complete coverage of an area this size is impossible, but we are refining our techniques in an attempt to cover representative sections of all types of habitat, in addition to canvassing every major slough, lake and reservoir in the region. As usual, the area was divided into quadrants but this year, for the first time, we had enough participants to field eight separate parties. Among the innovations was an attempt to count all individuals of 18 common species: Mallard, Coot, Willet, Marbled Godwit, Franklin's Gull, Black Tern, Rock Dove, Eastern Kingbird, Western Kingbird, Magpie, Crow, Mountain Bluebird, Loggerhead Shrike, Yellow Warbler, Western Meadow lark, Yellow-headed Blackbird, Red-winged Blackbird, and Clay-colored Sparrow. In addition, all individuals of every other species were counted until a total of 25 was reached; beyond that number, flocks of 50 or more were recorded. To facilitate counting, we prepared two sheets, both listing birds in alphabetic order rather than in A.O.U. sequence. Further changes may be introduced next year. In all likelihood, we will record total numbers only for those species readily observable from a moving car or gathered in large flocks on bodies of water. The idea is to increase our knowledge of changes in bird popula- 